To appear in Romance Linguistics: Structures, Interfaces, and Microparametric Variation ed. by Pascual J. Masullo, Erin O'Rourke, and Chia-Hui Huang. Amsterdam: John Benjamins

\title{
ON THE SYLLABIFICATION OF PREVOCALIC /w/ IN JUDEO-SPANISH ${ }^{*}$
}

\author{
TRAVIS G. BRADLEY \\ University of California, Davis
}

\begin{abstract}
Spanish prevocalic glides belong to the syllable nucleus except when no less sonorous segment is available to serve as onset (Harris 1983, Harris \& Kaisse 1999, Hualde 1989, 1991). Phonological innovations in a particular group of Judeo-Spanish dialects point to a novel generalization regarding the labiovelar glide, namely that $/ \mathrm{w} /$ is realized as secondary labialization on a preceding consonant. Evidence supporting this structural innovation comes from an asymmetry in the distribution of labialization. In these dialects, prevocalic /w/ strengthens to a labialized dorsal obstruent in syllable-initial position $\left(\mathrm{g}^{\mathrm{w}}\right.$ éso 'bone') but is realized as a secondary articulation on a preceding labial ( $\mathrm{p}^{\mathrm{w}}$ éðe 'can') or dorsal ( $\mathrm{k}^{\mathrm{w} e ́ . ð r a ~ ' r o p e ') . ~ L a b i a l i z e d ~ c o r o n a l s ~ a r e ~ d i s a l l o w e d ~ a n d ~ s h o w ~}$ several historical reflexes depending on the coronal's manner of articulation: nasal place assimilation $\left(\right.$ nwe $>\mathrm{m}^{\mathrm{w}} \mathrm{e}$ ), medial vowel epenthesis $\left(\mathrm{twe}>\mathrm{tur}^{\mathrm{w}} \mathrm{e}\right.$ ), and prothesis $\left(\mathrm{swe}>\operatorname{es} \mathrm{w}^{\mathrm{w}} \mathrm{e}\right)$. These innovations are analyzed in Optimality Theory in terms of interacting markedness and faithfulness constraints. The proposed account has implications for the issue of possible repair strategies, a.k.a. the "too-many-solutions" problem.
\end{abstract}

\section{Introduction}

In modern Spanish (henceforth, MS), prevocalic glides syllabify as onsets when no preceding consonant is available (1a) but are part of the syllable nucleus after a consonantal onset (1b) (Harris 1983, Harris \& Kaisse 1999, Hualde 1989, 1991).
(1) a. $\left[\mathrm{G}[\mathrm{V}]_{\mathrm{N}}\right]_{\sigma}$
b. $\left[\mathrm{C}[\mathrm{GV}]_{\mathrm{N}}\right]_{\sigma}$

Patterns of glide fortition provide supporting evidence for the difference in glide syllabification. In most dialects, the glides exhibit strengthened variants in syllable-initial position (2a) but not after a tautosyllabic consonant (2b).

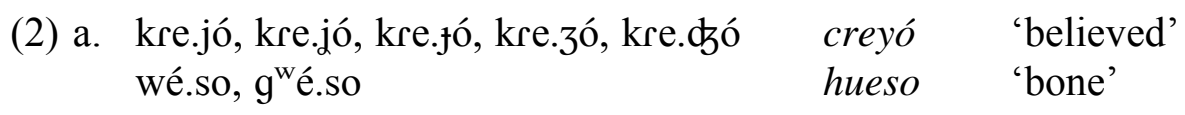

\footnotetext{
* For helpful comments and discussion, I would like to thank Gary Baker, Sonia Colina, CarlosEduardo Piñeros, and audience members at the $37^{\text {th }}$ Linguistic Symposium on Romance Languages, held March 15-18, 2007, by the University of Pittsburgh. This paper has also benefited from the comments of three anonymous reviewers. I am responsible for any shortcomings.
} 
$\begin{array}{lll}\text { b. kre.sjó } & \text { creció } & \text { 'grew' } \\ \text { pwén.te } & \text { puente } & \text { 'bridge' } \\ \text { twér.to } & \text { tuerto } & \text { 'twisted' } \\ \text { kwér.ða } & \text { cuerda } & \text { 'rope' }\end{array}$

Recent studies in phonological acquisition suggest the possibility of microparametric variation in the syllabification of postconsonantal glides in Spanish (Anderson 2002, Barlow 2005, Kehoe et al. 2008). For some children, glides seem to pattern as onsets even after a preceding consonant (3a). Another logical possibility, amply attested in other languages, is the realization of the glide as a secondary articulation on the preceding consonant (3b). Whereas the glide belongs to a complex onset cluster in (3a), it is part of a complex segment in (3b).
(3) a. $\left[\mathrm{CG}[\mathrm{V}]_{\mathrm{N}}\right]_{\sigma}$
b. $\left[\mathrm{C}^{\mathrm{G}}[\mathrm{V}]_{\mathrm{N}}\right]_{\sigma}$

This paper offers further evidence of (3b), based on phonological innovations involving the labiovelar glide in Judeo-Spanish (henceforth, JS) dialects. Data show that $/ \mathrm{w} /$ forms a complex segment with preceding labial or dorsal consonants but not with coronals. Inherited words that would have contained labialized coronals now show several historical reflexes depending on the manner of articulation of the coronal consonant. I propose an account of these innovations in Optimality Theory in terms of interacting markedness and faithfulness constraints. The analysis has implications for a larger theoretical debate regarding the overgeneration of possible repair strategies for a given structural constraint. Factorial typology predicts that vowel epenthesis can serve as a back-up repair for a markedness constraint that is otherwise responsible for place assimilation. Some researchers have denied the typological existence of such a repair, but empirical counterevidence comes from the innovations in coronal-/w/ sequences in JS: coronal $/ \mathrm{n} /$ undergoes regressive place assimilation, but non-nasals are resyllabified into a preceding syllable by vowel epenthesis.

\section{Data}

In a survey of synchronic variation within JS, Quintana (2006) identifies four dialect zones differing in the treatment of prevocalic /w/, summarized in Table 1.

\begin{tabular}{llcc}
\hline \multicolumn{1}{c}{ Dialect zone of JS } & Word-initial & $\begin{array}{c}\text { After coronal } \\
\text { stop/affricate }\end{array}$ \\
\hline A. & $\begin{array}{l}\text { Turkey, southeast Bulgaria, Greece, } \\
\text { Macedonia, Jerusalem }\end{array}$ & $\mathrm{gw}-$ & -urw- \\
B. $\begin{array}{l}\text { Greece, north Bulgaria, Rhodes, } \\
\text { Jerusalem }\end{array}$ & $\mathrm{bw}-\sim \mathrm{gw}-$ & $-\mathrm{uv}-$ \\
C. $\begin{array}{l}\text { Bosnia, Serbia, Croatia, Romania, south } \\
\text { central Bulgaria, Greece, Israel }\end{array}$ & $\mathrm{gw}-$ & $-\mathrm{w}-$ \\
D. Hebron, Jerusalem, Salonika & $\mathrm{w}-$ & $-\mathrm{w}-$ \\
\hline
\end{tabular}

Table 1: Diatopic variation in prevocalic /w/ (Quintana 2006:33-40) 
The present study focuses on type A varieties, which show strengthened velar variants word-initially and after coronal stops and affricates. For simplicity, the label 'JS' henceforth denotes type A varieties, unless stated otherwise. Data sources include Crews (1935), Crews \& Vinay (1939), Luria (1930), Penny (1992, 2000), Quintana (2006), Sala (1971), and Wagner (1914).

Diphthongization of the Latin short stressed /o/ ultimately produced /we/ in words like MS hueso < Latin ossum. Unstressed [o] and stressed [wé] are also found in morphophonological alternations in MS, e.g., [o.lér] oler 'to smell' vs. [wé.le] huele '(it) smells', [po.ðér] poder 'to be able' vs. [pwé.ðe] puede 'can'. The examples in (4) illustrate syllable-initial glide strengthening in JS and MS. In many MS varieties, there is variation between [we] and [gwe]/[rwe] in the absence of a preceding tautosyllabic consonant (Hualde 2005:171-172). In JS, however, syllable-initial [gwe]/[ywe] is obligatory and even reflected in the spelling: guele, gueko, etc. (cf. MS huele, hueco). ${ }^{1}$

(4)

$\begin{array}{lll}\underline{\text { JS }} \text { gwé.le } & \underline{\text { MS }} & \\ \text { gwé.ko } & \text { wé.le } \sim \text { gwé.le } & \text { '(it) smells' } \\ \text { gwér.ta } & \text { wé.ko } \sim \text { gwé.ko } & \text { 'hollow' } \\ \text { gwé.vo } & \text { wér.ta } \sim \text { gwér.ta } & \text { 'garden' } \\ \text { gwé.so } & \text { wé. } \beta 0 \sim \text { gwé. } \beta o & \text { 'egg' }\end{array}$

In both MS and JS, [w] appears after labial and dorsal onsets, as in $(5 \mathrm{a}, \mathrm{b})$. Whereas Latin short stressed /o/ is the etymological source of [we]/[gwe] in (4), the word-initial [gw] in (5b) derives from the /w/ of Germanic wardan.

(5)

\begin{tabular}{|c|c|c|}
\hline$\underline{\mathrm{JS}}$ & MS & \\
\hline pwé.ðe & pwé.ðe & 'can' \\
\hline bwen.dá(ð) & bon.dáð (cf. bwé.no 'good') & 'goodness' \\
\hline fwén.te & fwén.te & 'fountain' \\
\hline · kwé.ðra & kwér.ða & 'rope’ \\
\hline gwa.ðrár & gwas.ðás & 'to keep' \\
\hline
\end{tabular}

In $\mathrm{JS},[\mathrm{w}]$ is often inserted after labials and dorsals in the context of a preceding $/ \mathrm{u} /$, as seen in phrasal alternations (6a) and in word-internal contexts (6b). Quintana (2006:38) documents the innovative form [mwax.ke.mé], based on Turkish mahkeme 'trial, hearing'. Wagner (1914:114) explains the development of [w] on labials and velars after /u/ in Istanbul JS as a carryover effect of lip rounding. Crews and Vinay (1939:222) observe strong labialization of velar $[\gamma]$ in contact with /u/ in Salonika JS. To my knowledge, glide insertion after coronals is not attested in the descriptive literature.

\footnotetext{
${ }^{1}$ In most JS dialects, the voiced obstruents /bdg/ show the same allophonic distribution as in Peninsular Hispano-Romance varieties, with approximant [ $\beta \partial y]$ appearing in most positions and stop [bdg] only after a pause or nasal, and also after a lateral in the case of /d/ (Penny 1992:137). In the JS and MS data, strengthened /w/ shows the same distribution between [yw] and [gw].
} 
(6)

$\begin{array}{lll}\text { JS } & \underline{\text { MS }} & \\ \text { a. pwá.ðre } & \text { tu pá.ðre } & \text { 'your father' } \\ \text { el pá.ðre } & \text { el pá.ðre } & \text { 'the father' } \\ \text { tu mwá.ðre } & \text { tu má.ðre } & \text { 'your mother' } \\ \text { la má.ðre } & \text { la má.ðre } & \text { 'the mother' } \\ \text { un gwá.to } & \text { un gá.to } & \text { 'a cat' } \\ \text { es.te yá.to } & \text { es.te yá.to } & \text { 'this cat' } \\ \text { b. a.sú.kwar } & \text { a.sú.kar } & \text { 'sugar' } \\ \text { xa.nu.kwá } & \text { xa.nu.ká } & \text { 'Hanukah' } \\ \text { le.tfú.ywa } & \text { le.tfú.ya } & \text { 'lettuce' } \\ \text { lu.ywár } & \text { lu.yár } & \text { 'place' } \\ \text { tar.tú.ywa } & \text { tor.tú.ya } & \text { 'turtle' }\end{array}$

MS and JS differ with respect to coronal-/w/ sequences. In MS, [w] shows no sensitivity to the place of articulation of a preceding consonant and can appear freely after labials, coronals, and dorsals. In JS, however, the glide no longer appears after coronals, and inherited words that would have contained coronal-[w] sequences now have several historical reflexes. ${ }^{2}$ First, medial vowel epenthesis and glide strengthening are observed in sequences that contained an initial stop (7a), affricate (7b), or trill (7c).

(7) $\quad \underline{\mathrm{JS}}$
a. tu.ywér.to
tu. ¡wér.se
tru.ywé.no, tur.ywé.lo
du.ywé.le
du. ¡wér.me
b. đu. үwé.yo
Gu.ywé.ves
c. ru.ywé.ða

$\begin{array}{ll}\text { MS } & \\ \text { twér.to } & \text { 'twisted' } \\ \text { twér.se } & \text { 'twists' } \\ \text { trwé.no } & \text { 'thunder' } \\ \text { dwé.le } & \text { 'hurts' } \\ \text { dwér.me } & \text { 'sleeps' } \\ \text { xwé.yo } & \text { 'game' } \\ \text { xwé.jes } & \text { 'Thursday' } \\ \text { rwé.ða } & \text { 'wheel' }\end{array}$

Second, sequences containing /1/ or /s/ show prothesis, with fortition of the glide to $[\mathrm{\gamma w}]$ after $[1](8 \mathrm{a})$ and to partially voiceless $[\mathrm{Mw}]$ after $[\mathrm{s}](8 \mathrm{~b}) .^{3}$
$\underline{\mathrm{JS}}$
a. al.ywén.ga (< la lwén.ga)
el.ywé.yo
el.ywén.go
$\underline{\mathrm{MS}}$

$\begin{array}{ll}\text { lén.gwa } & \text { 'tongue' } \\ \text { lwé.yo } & \text { 'later' } \\ \text { lwén.go } & \text { 'long' }\end{array}$

\footnotetext{
${ }^{2}$ For a discussion of the relative chronology of most of these changes, see Quintana (2006:37-40).

${ }^{3}$ I transcribe the JS forms in (8b) following Penny (1992:137; see also Crews 1935:228), who argues that $/ \mathrm{w} /$ after word-initial $/ \mathrm{s} /$ was initially reinforced to a voiceless labiovelar fricative $[\mathrm{M}]$, then variably perceived as either [f] or [x] — both of which were existing segments in the language. Sala (1970:138; see also Wagner 1914:113) claims that the reinforcing element of the labiovelar glide was initially $[\mathrm{x}]$, which subsequently underwent a hypercorrective shift to $[\mathrm{f}]$ in those dialects in which historical /fwe/ had come to be realized as /xwe/.
} 
b. es.Mwé.no

es.Mwél.to

es.Mwé.yro

es.Mwé.ko

es.Mwé.lo

$\begin{array}{ll}\text { swé.no } & \text { 'sleep, dream' } \\ \text { swél.to } & \text { 'loose' } \\ \text { swé.yro } & \text { 'father-in-law' } \\ \text { swé.ko } & \text { 'clod' } \\ \text { swé.lo } & \text { 'ground' }\end{array}$

Finally, sequences containing $/ \mathrm{n} /$ show regressive place assimilation of the nasal, yielding bilabial $[\mathrm{m}]$ without vowel epenthesis or glide fortition (9a). The variants in (9b) presumably avoid homophony with the third person singular subjunctive form muera of morir 'to die' (Crews 1935:231). Luria (1930:107) attributes nasal assimilation "to the influence exercised by the semi-consonantal value of $w$ in we. This supposition is strengthened by the fact that we have nuvente 'NOVENTA' and not muvente."

(9) JS

$\begin{array}{ll}\text { a. } & \text { mwés } \\ \text { mwés.tro } \\ \text { mwé.ve } \\ \text { mwé.vo } \\ \text { mwe.vé.no } \\ \text { b. nwé.ra, nu.ywé.ra, er.mwé.ra }\end{array}$
$\underline{\mathrm{MS}}$

$\begin{array}{ll}\text { nwés } & \text { 'walnut' } \\ \text { nwés.tro } & \text { 'our' } \\ \text { nwé.ße } & \text { 'nine' } \\ \text { nwé.ßo } & \text { 'new' } \\ \text { no.ßéno } & \text { 'ninth' } \\ \text { nwé.ra } & \text { 'daughter-in-law' }\end{array}$

Table 2 summarizes the development of initial $/ \mathrm{Cw} /$ sequences from Old Spanish (OS) to MS and JS. (Note: $\{\mathrm{P}, \mathrm{K}\}$ denotes a labial or dorsal consonant, $\mathrm{T}$ denotes a coronal stop, affricate, or trill).

\begin{tabular}{cllllll}
\hline Variety & \multicolumn{2}{l}{ After labials \& dorsals } & \multicolumn{4}{c}{ After coronals } \\
\hline OS/MS & $\{\mathrm{P}, \mathrm{K}\}$ we & u. $\{\mathrm{P}, \mathrm{K}\} \mathrm{V}$ & Twe & lwe & swe & nwe \\
JS & $\{\mathrm{P}, \mathrm{K}\}$ we & u. $\{\mathrm{P}, \mathrm{K}\} \mathrm{wV}$ & Tu. $\gamma w e$ & el.ywe & es.Mwe & mwe \\
\hline
\end{tabular}

Table 2: Summary of /Cw/ developments

Several questions emerge from these regular sound correspondences. Why is prevocalic $/ \mathrm{w} /$ sensitive to the place of articulation of a preceding consonant in JS but not in OS and MS? In JS, why has $/ \mathrm{n} /$ become labial while non-nasal coronals show vowel epenthesis? Why do coronal obstruents and the trill show medial vowel epenthesis but the lateral and /s/ show prothesis?

\section{Variation in the syllabification of prevocalic /w/ in JS and MS}

The asymmetrical distribution shown in Table 2 is consistent with the view that prevocalic $/ \mathrm{w} /$ in JS is realized as secondary labialization on a preceding consonant. On this view, the restriction on the type of consonant the labiovelar glide can combine with is predicted, since coalescence of the two segments into a single one is naturally subject to the condition that their features be compatible. Empirical support for this view comes from distributional asymmetries observed 
in other languages. Based on Ruhlen's (1976) catalogue of the segment inventories of 706 languages, Ohala \& Lorentz (1977:580-581) find that contrastive labialization occurs more often on velar, uvular, and labial consonants than on dental, alveolar, or palatal. In fact, $54 \%$ of the 584 languages with contrastive labialization in Ruhlen's survey have one or more labialized velars, which suggests that velars are universally favored as targets of secondary labialization. In Chaha and Inor, spoken in the West Gurage region of Ethiopa, the masculine morpheme is realized as labialization on the rightmost labial or velar consonant of the stem but never on coronals (Rose 1994). In Trique, a Mixtecan language spoken in Mexico, a sound change has occurred whereby velars following the vowel $/ \mathrm{u} /$ are labialized while coronals appearing in the same context are not (Hollenbach 1977). The patterning of /w/ in JS parallels the crosslinguistic tendency of coronals to avoid secondary labialization.

Consider the different syllabifications of /Cwe/ sequences illustrated in (10). As we have seen, prevocalic glides in MS form a complex nucleus with the following vowel, unless no other consonant is available to serve as onset. The nuclear status of $/ \mathrm{w} /$ accounts for the fact that this glide can occur with preceding labials, coronals, and dorsals in (10a). JS allows /w/ to group with a preceding labial or dorsal consonant but not with a preceding coronal. This asymmetry strongly suggests that prevocalic $/ \mathrm{w} /$ in JS forms a complex segment with a preceding consonant, where it is subject to a cooccurrence constraint against labialized coronals. This constraint accounts for the distributional gap in (10b).
a. MS: $\frac{\text { Labial }}{\left[\mathrm{C}[\mathrm{we}]_{\mathrm{N}}\right]_{\sigma}}$
Coronal
Dorsal
b. JS:
$\left[\mathrm{C}^{\mathrm{w}}[\mathrm{e}]_{\mathrm{N}}\right]_{\sigma}$
$\left[\mathrm{C}[\mathrm{we}]_{\mathrm{N}}\right]_{\sigma}$
$\left[\mathrm{C}[\mathrm{we}]_{\mathrm{N}}\right]_{\sigma}$
$\left[\mathrm{C}^{\mathrm{w}}[\mathrm{e}]_{\mathrm{N}}\right]_{\sigma}$

Several recent studies have analyzed glide syllabification in Romance within Optimality Theory (henceforth, OT; Prince \& Smolensky 1993/2004). Bullock (2002) accounts for the distribution of peak and margin glides in French. Baker \& Wiltshire (2003) and Wiltshire (2007) analyze fortition patterns affecting the palatal glide in Argentinian Spanish. Colina (2007) gives a comprehensive OT account of Spanish syllable types, phonotactic restrictions, syllabification algorithms and domains, and repair strategies. Other studies have accounted for patterns of secondary labialization with cooccurrence constraints on labialized consonants (Akinlabi 1996 and Zoll 2001).

Building upon these previous works, I develop an OT analysis of $/ \mathrm{w} /$ syllabification that straightforwardly accounts for the MS and JS patterns in terms of different constraint rankings. First, I adopt a universal ranking of cooccurrence constraints in (11), which reflects the cross-linguistic preference for labialized dorsals over labialized coronals and labials. (Note: I make no particular claims in this paper about the feature geometry of labialized consonants.) Languages may differ with respect to the ranking of ${ }^{*} \mathrm{~T}^{\mathrm{w}}$ and ${ }^{*} \mathrm{P}^{\mathrm{w}}$, but ex hypothesi the ranking of ${ }^{*} \mathrm{~K}^{\mathrm{w}}$ below these two constraints is fixed in all languages.

$$
* \mathrm{~T}^{\mathrm{w}},{ }^{*} \mathrm{P}^{\mathrm{w}} \gg * \mathrm{~K}^{\mathrm{w}}
$$


Second, I adopt the markedness and faithfulness constraints in (12). The markedness hierarchies in $(12 \mathrm{a}, \mathrm{b})$ are derived by harmonic alignment of sonority and syllabic prominence scales (see Colina 2007:179-180 and McCarthy 2002:21). These universal rankings encode a general preference for less sonorous segments to occur in the syllable onset (12a) and for more sonorous segments to occur in the syllable nucleus. ${ }^{*}$ ONS/GLIDE and $*$ NUC/GLIDE are crucial constraints in the analysis to come. (12c) penalizes a syllable that lacks an onset. The faithfulness constraint in $(12 \mathrm{~d})$ is violated when an input glide is strengthened to an obstruent in the output.

(12) a. *ONS/GLIDE »*ONS/LIQ »*ONS/NAS »*ONS/FRIC »*ONS/STOP

b. $*$ NUC/STOP »*NUC/FRIC »*NUC/NAS »*NUC/LIQ »*NUC/GLIDE

c. ONSET

A syllable must have an onset.

d. IDENT(son)

The specification for the feature [sonorant] of an input segment must be preserved in the segment's output correspondent.

Consider first how the grammar of MS handles inputs such as /wele/ 'stinks' and /pwede/ 'can'. I assume that the morphophonological alternation between /o/ and /we/ in oler vs. huele and poder vs. puede can be analyzed in terms of phonological selection between listed allomorphs (see Bermúdez-Otero 2007). Due to space limitations, only forms with diphthongs are treated here. In the following tableaux, relevant syllable nuclei are enclosed within brackets in output candidates, and syllable divisions are indicated by periods. For /wele/ in Tableau 1, high-ranking ONSET rules out candidates $(\mathrm{a}, \mathrm{b})$ because they contain onsetless syllables. Candidate (c) parses the input glide as an onset, fatally violating *ONS/GLIDE. Candidates $(\mathrm{d}, \mathrm{e})$ strengthen the glide to a labialized obstruent, violating low-ranking IDENT(son). The hierarchy in (11) selects the labialized dorsal in candidate (d) as the winner. The variable fortition observed in (4) suggests a variable ranking between $*$ ONS/GLIDE and $* \mathrm{~K}^{\mathrm{w}}$. Candidate (c) is optimal when the former constraint happens to fall below the latter.

\begin{tabular}{|c|c|c|c|c|c|c|c|c|}
\hline & /wele/ 'stinks' & ONSET & $\begin{array}{ll}* \mathrm{~T}^{\mathrm{w}} \\
\end{array}$ & $* \mathrm{P}^{\mathrm{w}}$ & \begin{tabular}{|ll} 
*ONS/ \\
GLIDE \\
\end{tabular} & $* \mathrm{~K}^{\mathrm{w}}$ & $\begin{array}{l}{ }^{*} \mathrm{NUC} / \\
\text { GLIDE }\end{array}$ & $\begin{array}{l}\text { IDENT } \\
\text { (son) } \\
\end{array}$ \\
\hline & [wé].le & $* !$ & ? & & 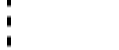 & & $*$ & 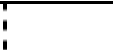 \\
\hline & [u].[é].le & $* ! *$ & $T$ & & 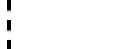 & & & 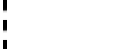 \\
\hline$c$ & w[é].le & & 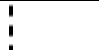 & 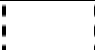 & $* !$ & & & ! \\
\hline$\leftrightarrow \mathrm{d}$ & $\mathrm{g}^{\mathrm{w}}[\mathrm{e}] \cdot l \mathrm{le}$ & & ! & ! & i & $*$ & & $*$ \\
\hline $\mathrm{e}$ & $\mathrm{b}^{\mathrm{w}}[\mathrm{e}]$ ]le & & ; & $* !$ & $\vdots$ & & & $*$ \\
\hline
\end{tabular}

Tableau 1: Fortition of prevocalic /w/ to labialized dorsal $\left[\mathrm{g}^{\mathrm{w}}\right]$ in $M S$

For /pwede/ in Tableau 2, the initial stop in candidate (a) satisfies ONSET. Candidates (b) with an onsetless syllable and (c) with an onset glide are ruled out 
by ONSET and *ONS/GLIDE, respectively. The constraint against labialized labials eliminates candidate (d), and candidate (a) with the nuclear glide emerges as optimal. Strengthening in complex onsets (e.g., $\mathrm{pg}^{\mathrm{w}}[\mathrm{e}]$.ðe) is ruled out by a highranking constraint not shown here, requiring a maximal sonority distance between the members of an onset cluster (see Colina 2007:183).

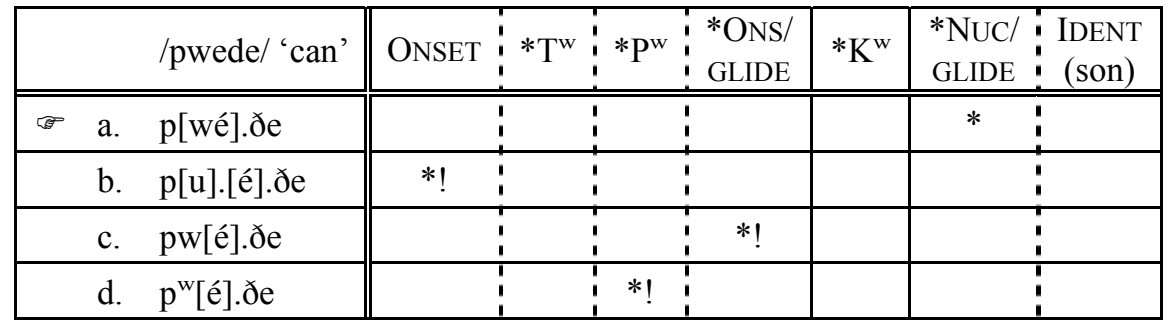

Tableau 2: Complex nucleus containing $/ \mathrm{w} /$ in MS

In the JS grammar, ${ }^{*}$ NUC/GLIDE dominates both ${ }^{*} \mathrm{P}^{\mathrm{w}}$ and ${ }^{*} \mathrm{~K}^{\mathrm{w}}$, which forces $/ \mathrm{w} /$ out of the syllable nucleus and onto a preceding labial or dorsal as secondary labialization. For an input such as /wele/, high-ranking ONSET and *ONS/GLIDE still favor glide fortition, and $\mathrm{g}^{\mathrm{w}}[\mathrm{e}]$.le wins as in MS (see Tableau 1). The obligatory nature of fortition observed in (4) suggests that *ONS/GLIDE maintains a high ranking in the JS grammar. For /pwede/ in Tableau 3, high-ranking *NUC/GLIDE eliminates candidate (a) with the nuclear glide, and candidate (d) with a labialized labial emerges as optimal.

\begin{tabular}{|c|c|c|c|c|c|c|}
\hline /pwede/ 'can' & ONSET & $* \mathrm{~T}^{\mathrm{w}}$ & $\begin{array}{l}* \text { ONS } \\
\text { GLIDE }\end{array}$ & $\begin{array}{l}* \text { NUC/ } \\
\text { GLIDE }\end{array}$ & $* \mathrm{P}^{\mathrm{w}}$ & $\begin{array}{c:c}\mathrm{K}^{\mathrm{w}} & \text { IDENT } \\
\text { (son) }\end{array}$ \\
\hline a. p[wé].ðe & & 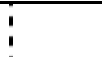 & 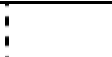 & $* !$ & & $i$ \\
\hline b. $\quad \mathrm{p}[\mathrm{u}]$ ].[é].ðe & $* !$ & 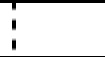 & 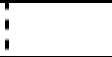 & & & : \\
\hline c. pw[é].ðe & & 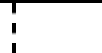 & $* !$ & & & 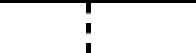 \\
\hline d. $\mathrm{p}^{\mathrm{w}}[\mathrm{e}]$. . & & $!$ & 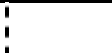 & & * & $!$ \\
\hline
\end{tabular}

Tableau 3: Prevocalic /w/ realized as secondary labialization in JS

A comparison of Tableau 2 and Tableau 3 highlights the principal difference in syllabification of input /Cwe/ between the two dialects: /w/ forms a complex nucleus with the following vowel in MS, whereas /w/ forms a complex segment with a preceding labial or velar consonant in JS.

\section{The avoidance of labialized coronals in JS}

\subsection{Place assimilation vs. vowel epenthesis}

In the JS data, nasals pattern differently from obstruents in the resolution of etymological coronal-/w/ sequences. In (7) and (8), vowel epenthesis moves a non-nasal coronal into the preceding syllable. In (9), place assimilation produces a labial nasal, which can accommodate secondary labialization. The greater susceptibility of nasals to undergo place assimilation is expected, since acoustic 
cues to nasal place are universally weaker than place cues for obstruents (Jun 2004, Padgett 1995; see also Colina 2007, Piñeros 2007 for analyses of Spanish). The asymmetry can be accounted for by relativizing place faithfulness to different manner classes, as shown in $(13 \mathrm{a}, \mathrm{b})$. The ranking of IDENT $_{\mathrm{OBs}}($ place) » IDENT $_{\text {NAS }}$ (place) is universal, present in all languages. In JS, the anti-epenthesis constraint $(13 \mathrm{c})$ is ranked between these two faithfulness constraints.

(13) a. IDENT ${ }_{\text {OBs }}($ place $)$

The primary place features of an input obstruent segment must be preserved in the segment's output correspondent.

b. $\operatorname{IDENT}_{\mathrm{NAS}}$ (place)

The primary place features of an input nasal segment must be preserved in the segment's output correspondent.

c. $\operatorname{Dep}(\mathrm{V})$

Every vowel in the output has a correspondent in the input.

Tableau 4 illustrates the vowel epenthesis repair, given the input/twerto/ 'twisted'. To simplify the presentation, candidates with hiatus or nuclear/onset glides are no longer considered. Candidate (a) with a labialized coronal is eliminated by high-ranking $* \mathrm{~T}^{\mathrm{w}}$. Candidates $(\mathrm{b}, \mathrm{c})$ change the primary place feature of the input obstruent, fatally violating $\operatorname{IDENT}_{\mathrm{OBs}}$ (place). Medial vowel epenthesis in candidate (d) can be understood as a way to both avoid the labialized coronal and maintain the place feature of the obstruent.

\begin{tabular}{|c|c|c|c|}
\hline /twerto/ 'twisted' & $\begin{array}{c:c}* \mathrm{~T}^{\mathrm{w}} & \text { IDENT }_{\mathrm{OBS}} \\
\text { (place) }\end{array}$ & $\begin{array}{l}\text { DEP } \\
(\mathrm{V})\end{array}$ & $\begin{array}{c}\text { IDENT }_{\text {NAS }} \\
\text { (place) }\end{array}$ \\
\hline a. $\mathrm{t}^{\mathrm{w}}[\mathrm{e}]$ r.to & $* !$ & & \\
\hline b. $\quad \mathrm{p}^{\mathrm{w}}[\mathrm{e}]$ ].to & $* !$ & & \\
\hline c. $\mathrm{k}^{\mathrm{w}}[\mathrm{e}]$ r.to & $* !$ & & \\
\hline $\begin{array}{lll}\sigma^{2} & \text { d. }[\mathrm{V}] \cdot \gamma^{\mathrm{w}}[\mathrm{e}] \text { r.to }\end{array}$ & & * & \\
\hline
\end{tabular}

Tableau 4: Labialized coronal stop resolved by medial vowel epenthesis

The analysis of nasal place assimilation requires a constraint against syllableinitial [y]. Colina and Díaz-Campos (2006) employ such a constraint in their analysis of intervocalic velar nasals in Galician. In both JS and MS, syllableinitial $/ \mathrm{y} /$ does not contrast with labial $/ \mathrm{m} /$, coronal $/ \mathrm{n} /$, and palatal $/ \mathrm{n} /$, which suggests that $*$ ONS/y outranks $\operatorname{IDENT}_{\mathrm{NAS}}$ (place). For /nwes/ 'walnut' in Tableau 5, vowel epenthesis in candidate $(\mathrm{d})$ is now ruled out by $\operatorname{DEP}(\mathrm{V}) .{ }^{*} \mathrm{ONS} / \mathrm{y}$ prefers candidate (b) with the labial nasal over candidate (c) with the dorsal nasal. Note that $\operatorname{IDENT}_{\mathrm{OBS}}$ (place) and $\operatorname{IDENT}_{\mathrm{NAs}}$ (place) are irrelevant for non-nasal sonorants. The failure of $/ \mathrm{r} /$ and $/ 1 /$ to undergo place assimilation must be explained in some other way. This might involve feature cooccurrence constraints against noncoronal rhotics and laterals, which do not otherwise occur in JS. Developing a 
complete account would lead us too far afield, but see Yip (2004), who uses cooccurrence constraints to account for cross-linguistic patterns involving laterals.

\begin{tabular}{|c|c|c|c|c|}
\hline /nwes/ 'walnut' & $\begin{array}{c:c}* T^{\mathrm{w}} & \text { IDENT }_{\mathrm{OBS}} \\
\text { (place) }\end{array}$ & $\begin{array}{l}\text { DEP } \\
(V)\end{array}$ & $\begin{array}{c}* \text { Ons/ } \\
y\end{array}$ & $\begin{array}{c}\text { IDENT }_{\text {NAS }} \\
\text { (place) }\end{array}$ \\
\hline a. $\mathrm{n}^{\mathrm{w}}$ [é]s & *! & & & \\
\hline$\leftrightarrow \quad$ b. $\quad \mathrm{m}^{\mathrm{w}}[\mathrm{e}] \mathrm{s}$ & !' & & & $*$ \\
\hline c. $\eta^{\mathrm{w}}[\mathrm{e}] \mathrm{s}$ & i & & *! & $*$ \\
\hline d. $\quad \mathrm{n}[\mathrm{V}] \cdot \gamma^{\mathrm{w}}[\mathrm{é}] \mathrm{s}$ & : & $* !$ & & \\
\hline
\end{tabular}

Tableau 5: Labialized coronal nasal resolved by nasal place assimilation

\subsection{Prothesis vs. medial vowel epenthesis}

Coronal obstruents and the trill show medial vowel epenthesis in (7), but the lateral and /s/ show prothesis in (8). This asymmetry can be captured by the interaction of the constraints in (14). The universal hierarchy in (14a) encodes a preference for more sonorous segments to occur in the syllable coda (Colina 2007:180,188). The faithfulness constraint in (14b) is violated by epenthesis within a segmental string but not by epenthesis at the edges of the string.

(14) a. *CODA/STOP $» *$ CODA/FRIC » *CODA/NAS » *CODA/LIQ »*CODA/GLI

b. CONTIGUity

Elements adjacent in the input must be adjacent in the output.

Tableau 6 illustrates the resolution of an input such as /twerto/. In this and subsequent tableaux, output candidates show only the initial portion of the input string. Candidates $(b, c)$ avoid the labialized coronal of candidate (a) but differ in the locus of vowel epenthesis. Candidate (b) with medial vowel epenthesis violates CONTIGUITY, whereas candidate (c) with prothesis violates *CODA/STOP. The ranking of *CODA/STOP » CONTIGUITY captures the generalization that it is better to avoid syllabifying the stop in coda position than to maintain adjacency of input segments in the output.

\begin{tabular}{|cc||c|c:c|c|}
\hline & $/$ twerto/ 'twisted' & $* \mathrm{~T}^{\mathrm{w}}$ & $\begin{array}{c}\text { DEP } \\
(\mathrm{V})\end{array}$ & $\begin{array}{c}\text { CODA/ } \\
\text { STOP }\end{array}$ & CONTIGUITY \\
\hline \hline a. $\quad \mathrm{t}^{\mathrm{w}}[\mathrm{e}]$ & $* !$ & & & \\
\hline b. $\quad \mathrm{t}[\mathrm{V}] \cdot \mathrm{g}^{\mathrm{w}}[\mathrm{é}]$ & & $*$ & & $*$ \\
\hline c. $\quad[\mathrm{V}] \mathrm{t} . \mathrm{g}^{\mathrm{w}}[\mathrm{é}]$ & & $*$ & $* !$ & \\
\hline
\end{tabular}

\section{Tableau 6: Medial vowel epenthesis after coronal stop}

Tableau 7 illustrates the resolution of input /lwe/ and /swe/ sequences. For /lwego/, candidate (b) with medial vowel epenthesis violates CONTIGUITY. Candidate (c) with a coda lateral violates low-ranking * CODA/LIQ. The analysis is the same for $/$ sweno/, except that candidate (f) with a coda fricative violates 
*CODA/FRIC. The ranking of CONTIGUITY above both *CODA/FRIC and *CODA/LIQ captures the generalization that it is better to insert an initial vowel than to avoid syllabifying the fricative or lateral in coda position.

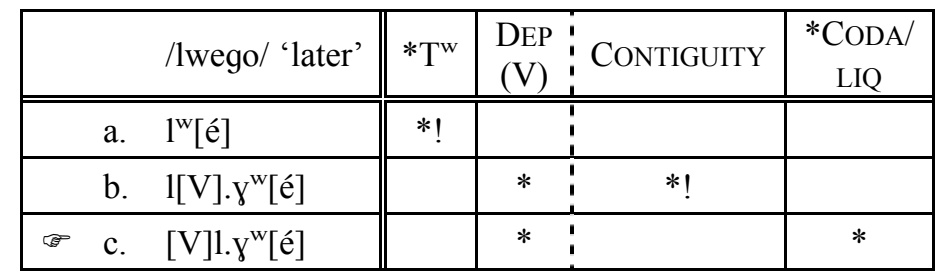

\begin{tabular}{|cl||c|c|c|c|}
\hline & /sweno/ 'sleep' & $* T^{\mathrm{w}}$ & $\begin{array}{c}\text { DEP } \\
(\mathrm{V})\end{array}$ & CONTIGUITY & $\begin{array}{c}{ }^{*} \text { CODA/ } \\
\text { FRIC }\end{array}$ \\
\hline \hline d. & $\mathrm{s}^{\mathrm{w}}[\mathrm{e}]$ & $* !$ & & & \\
\hline e. & $\mathrm{s}[\mathrm{V}] \cdot \mathrm{r}^{\mathrm{w}}[\mathrm{é}]$ & & $*$ & $* !$ & \\
\hline f. & {$[\mathrm{V}] \mathrm{s} \cdot \mathrm{M}^{\mathrm{w}}[\mathrm{é}]$} & & $*$ & & $*$ \\
\hline
\end{tabular}

Tableau 7: Prothesis before coronal lateral and fricative

\section{Theoretical comparisons and implications}

One alternative is to view $/ \mathrm{Cw} /$ as a complex onset cluster, as in (3a), and to invoke a constraint such as ${ }^{*} \mathrm{ONS} / \mathrm{COR}-[\mathrm{w}]$ to rule out coronal-[w] onsets. An anonymous reviewer suggested that even the strengthened glide in words like gwé.le '(it) smells' might be represented as a complex onset, as some of the JS data seem to point in this direction. The type B varieties in Table 1 show wordinitial strengthening with free variation between labial and velar obstruents. If strengthening implies adding a segment, then type $\mathrm{A}$ and $\mathrm{B}$ varieties would differ only with respect to the choice of inserted obstruent, and the analysis could be based on the same constraints that account for the general distribution of $[\mathrm{w}]$ in onset clusters. However, the brute-force constraint *ONS/COR-[w] seems highly specific and lacks credibility as a universal principle. The requirement that the segments of input $/ \mathrm{Cw} /$ have at least one place specification in common makes much more sense under the complex segment analysis, since coalescence of the two segments into a single one naturally requires that their features be compatible. The complex segment analysis also situates JS within a broader cross-linguistic typology of secondary labialization patterns, as captured by the universal ranking in (11). Furthermore, glide strengthening need not imply adding an entire segment in order to account for the variation between complex segments $\left[\mathrm{b}^{\mathrm{w}}\right]$ and $\left[\mathrm{g}^{\mathrm{w}}\right]$, which are simply two labialized obstruents that differ in their primary, consonantal place of articulation. The universal ranking of $* \mathrm{P}^{\mathrm{w}} \gg * \mathrm{~K}^{\mathrm{w}}$ invariably predicts $\left[\mathrm{g}^{\mathrm{w}}\right]$ as the outcome of strengthening. However, interaction between $* \mathrm{P}^{\mathrm{w}}$ and some other markedness constraint (e.g., against consonants with dorsal place) can easily account for the variation. The analysis would also need to explain why in type B dialects, $\left[b^{\mathrm{w}}\right]$ varies freely with $\left[\mathrm{g}^{\mathrm{w}}\right]$ in word-initial contexts while labiodental [v] is preferred word-medially. Clearly, more research is called for. 
The present study has not focused at all on the behavior of the palatal glide $/ \mathrm{j} /$ in JS. If the labiovelar and palatal glides were to behave asymmetrically, then it would be of essence to investigate why this should be so. Is this language trying to avoid all rising diphthongs or just rising diphthongs with $/ \mathrm{w} /$ ? If the latter, then why are rising diphthongs with $/ \mathrm{j} /$ immune to the structural changes that are being enforced? Quintana (2006:92-93, 380) observes the palatalization of $/ \mathrm{k} / \mathrm{and} / \mathrm{g} /$ following stressed /i/ in some JS dialects, and Kovačec (1986-1987:164) also finds similar effects involving / $\mathrm{t} / \mathrm{and} / \mathrm{d} / \mathrm{before}$ the palatal glide. Interestingly, palatalization has been documented in areas that largely correspond to dialect zone $\mathrm{C}$ of Table 1 , where prevocalic /w/ apparently fails to show any sensitivity to a preceding tautosyllabic consonant. This geographical distribution suggests that palatalization and labialization are two separate phenomena that can occur independently of each other. Their independence is predicted by an OT analysis that assumes separate constraints for labialized and palatalized consonants. The ranking of $*$ ONS/GLIDE $» * \mathrm{NUC} / \mathrm{GLIDE}$ enforces a general preference for nuclear glides, and the ranking of ${ }^{*} \mathrm{C}^{\mathrm{w}}$ and ${ }^{*} \mathrm{C}^{\mathrm{j}}$ constraints with respect to ${ }^{*} \mathrm{NUC} / \mathrm{GLIDE}$ determines which types of complex segments are allowed.

The present study also contributes to an ongoing debate in the OT literature regarding the overgeneration of possible repair strategies (a.k.a. the "too many solutions" problem). Factorial typology predicts epenthesis and deletion as possible back-up repairs for markedness constraints requiring feature assimilation or sharing between segments (Bakovic 2007). Some researchers take the position that such repairs are typologically unattested and propose theoretical explanations for the gap. Steriade (2001) invokes a perceptually-based, universal ranking of

correspondence constraints. Pater (2003) argues for a universal ranking of segmental correspondence constraints above markedness constraints on feature sharing. Bakovic \& Wilson (2004) make use of perceptually-based, targeted markedness constraints. Other researchers take the opposite position, arguing instead that epenthesis and deletion are used in some languages as back-up strategies to assimilation. See de Lacy (2006) for an analysis of epenthesis in Ponapean and deletion in Attic Greek, and Bakovic (2007) on epenthesis in English and both epenthesis and deletion in Lithuanian.

The JS data analyzed in the present study provide further evidence in favor of vowel epenthesis as an alternate repair for a markedness constraint that is otherwise responsible for place assimilation. As we have seen, labialized coronals are marked structures in JS that violate the high-ranking constraint ${ }^{*} \mathrm{~T}^{\mathrm{w}}$. If the coronal is nasal, then the illicit complex segment is repaired by changing the primary place feature of $/ \mathrm{n} /$ to labial, which is compatible with secondary labialization. If the coronal is non-nasal, then vowel epenthesis applies instead, moving the coronal to the preceding syllable. These repairs are predicted by the ranking of $\operatorname{DEP}(\mathrm{V})$ between two manner-specific IDENT(place) constraints.

\section{Conclusion}

Harris \& Kaisse (1999:129) summarize what one might call the "generative consensus" regarding the syllabification of prevocalic glides in MS: 
"[A] number of arguments converge on the conclusion that Spanish prevocalic glides form onsets when no less sonorous segment is available to fill that position but are assigned to rhymes (complex nuclei) when a consonantal onset is available. These arguments hold mutatis mutandis in all the major dialects of Spanish, and no viable counterarguments are known."

This generalization may be true for many dialects of MS, but it remains an empirical question whether the same can be said for all Spanish varieties.

In this paper, I have argued that JS dialects spoken in Turkey, southeast Bulgaria, Greece, Macedonia, and Jerusalem show phonologically innovative patterns that are consistent with the syllabification of prevocalic $/ \mathrm{w} /$ as part of a complex segment. Evidence for the difference comes from the fact that $/ \mathrm{w} /$ is sensitive to the place of articulation of a preceding consonant. While labialized labials and dorsals are allowed, labialized coronals are repaired through nasal place assimilation or vowel epenthesis, depending on the manner specification of the initial consonant. The JS data also bear on the typology of repair strategies in OT, providing further evidence of vowel epenthesis as an attested back-up repair for a markedness constraint that is otherwise responsible for place assimilation.

\section{REFERENCES}

Akinlabi, Akinbiyi. 1996. "Featural Affixation". Journal of Linguistics 32.239289.

Anderson, Raquel. 2002. "Onset Clusters and the Sonority Sequencing Principle in Spanish: A treatment efficacy study". Investigations in Clinical Phonetics and Linguistics ed. by Fay Windsor, M. Louise Kelly \& Nigel Hewlett, 213224. Mahwah, NJ: Erlbaum.

Baker, Gary \& Caroline Wiltshire. 2003. "An OT Treatment of Palatal Fortition in Argentinian Spanish". Romance Linguistics: Theory and Acquisition ed. by Ana Teresa Pérez-Leroux \& Yves Roberge, 33-48. Amsterdam: John Benjamins.

Bakovic, Eric. 2007. "Local Assimilation and Constraint Interaction". The Cambridge Handbook of Phonology ed. by Paul de Lacy, 335-352. Cambridge: Cambridge University Press.

------- \& Colin Wilson. 2004. "Laryngeal Markedness and the Typology of Repair". Paper presented at the 78th Annual Meeting of the LSA, Boston, 2004. Barlow, Jessica. 2005. "Phonological Change and the Representation of Consonant Clusters in Spanish: A case study". Clinical Linguistics and Phonetics, 19.659-679.

Bermúdez-Otero, Ricardo. 2007. "Morphological Structure and Phonological Domains in Spanish Denominal Derivation". Optimality-theoretic Studies in Spanish Phonology ed. by Fernando Martínez-Gil \& Sonia Colina, 278-311. Amsterdam: John Benjamins.

Bullock, Barbara. 2002. "Constraining the Vagaries of Glide Distribution in Varieties of French". Romance Phonology and Variation ed. by Caroline Wiltshire \& Joaquim Camps, 11-25. Amsterdam: John Benjamins. 
Colina, Sonia. 2007. "Optimality-theoretic Advances in our Understanding of Spanish Syllable Structure". Optimality-theoretic Studies in Spanish Phonology ed. by Fernando Martínez-Gil \& Sonia Colina, 172-204. Amsterdam: John Benjamins.

-------- \& Manuel Díaz-Campos. 2006. "The Phonetics and Phonology of Intervocalic Velar Nasals in Galician”. Lingua 118:8.1245-1273.

Crews, Cynthia. 1935. Recherches sur le judéo-espagnol dans les pays balkaniques. Paris: Droz.

-------- \& Vinay, J. P. 1939. "Quelques observations supplémentaires sur le parler judéo-espagnol de Salonique". Bulletin Hispanique 41.209-235.

de Lacy, Paul. 2006. Markedness: Reduction and Preservation in Phonology. Cambridge: Cambridge University Press.

Harris, James. 1983. Syllable Structure and Stress in Spanish: A nonlinear analysis. Cambridge: MIT Press.

---ar- \& Kaisse, Ellen. 1999. "Palatal Vowels, Glides and Obstruents in Argentinian Spanish". Phonology 16.117-190.

Hollenbach, Barbara. 1977. "Phonetic versus Phonemic Correspondence in Two Trique Dialects". Studies in Otomanguean Phonology ed. by W.R. Merrifield, 35-68. Dallas: Summer Institute of Linguistics.

Hualde, José Ignacio. 1989. "Silabeo y estructura morfémica en español". Hispania 72.821-831.

--------. 1991. "On Spanish Syllabification". Current Studies in Spanish Linguistics ed. by Héctor Campos \& Fernando Martínez-Gil, 475-493. Washington, DC: Georgetown University Press.

-------. 2005. The Sounds of Spanish. Cambridge: Cambridge University Press.

Jun, Jongho. 2004. "Place Assimilation". Phonetically-based Phonology ed. by Bruce Hayes, Robert Kirchner \& Donca Steriade, 58-86. Cambridge: Cambridge University Press.

Kehoe, Margaret, Geraldine Hilaire-Debove, Katherine Demuth \& Conxita Lleo. 2008. "The Structure of Branching Onsets and Rising Diphthongs: Evidence from the Acquisition of French and Spanish". Language Acquisition: A Journal of Developmental Linguistics 15:1.5-57.

Kovačec, August. 1986-1987. "Sobre el valor de las unidades [t] ([ḱ, k', ć, ki] ) y [d] ([ǵ, g', đ, gị]) en el judeo-español de Sarajevo y Dubrovnik". Studia Romanica et Anglica Zagrabiensia 31-32.156-169.

Luria, Max. 1930. A Study of the Monastir Dialect of Judeo-Spanish based on Oral Material Collected in Monastir, Yugo-Slavia. New York: Instituto de las Españas de los Estados Unidos.

McCarthy, John. 2002. A Thematic Guide to Optimality Theory. Cambridge: Cambridge University Press.

Ohala, John. J. \& Lorentz, James. 1977. "The Story of [w]: An exercise in the phonetic explanation for sound patterns". Proceedings of the Berkeley Linguistics Society 3.577-599.

Padgett, Jaye. 1995. "Partial Class Behavior and Nasal Place Assimilation". Arizona Phonology Conference: Proceedings of the South Western Optimality 
Theory Workshop, vol. 5 Coyote Papers ed. by Keiichiro Suzuki \& Dirk Elzinga, 145-183. Tucson: University of Arizona.

Pater, Joe. 2003. "Balantak Metathesis and Theories of Possible Repair in Optimality Theory". Ms., University of Massachusetts, Amherst.

Penny, Ralph. 1992. "Dialect Contact and Social Networks in Judeo-Spanish". Romance Philology 46.125-140.

--------. 2000. Variation and Change in Spanish. Cambridge: Cambridge University Press.

Piñeros, Carlos-Eduardo. 2007. "The Phonology of Nasal Consonants in Five Spanish Dialects". Optimality-theoretic Studies in Spanish Phonology ed. by Fernando Martínez-Gil \& Sonia Colina, 146-171. Amsterdam: John Benjamins.

Prince, Alan \& Paul Smolensky. 1993. "Optimality Theory: Constraint Interaction in Generative Grammar". Ms., New Brunswick and Boulder: Rutgers University and University of Colorado.

--------. 2004. Optimality Theory: Constraint Interaction in Generative Grammar. Malden, MA: Blackwell.

Quintana, Aldina. 2006. Geografía lingüística del judeoespañol: estudio sincrónico y diacrónico. Bern: Peter Lang.

Rose, Sharon. 1994. "The Historical Development of Secondary Articulation in Gurage". Proceedings of the Berkeley Linguistics Society 20.112-124.

Ruhlen, Merritt. 1976. A Guide to the Languages of the World. Stanford: Language Universals Project.

Sala, Marius. 1971. Phonétique et phonologie du judéo-espagnol de Bucharest. The Hague: Mouton.

Steriade, Donca. 2001. "The Phonology of Perceptibility Effects: The P-map and its consequences for constraint organization". Ms., University of California, Los Angeles.

Wagner, Max Leopold. 1914. Beiträge zur Kenntnis des Judenspanischen von Konstantinopel. Wien: Hölder.

Wiltshire, Caroline. 2007. "Prefix Boundaries in Spanish Varieties: A nonderivational OT account". Optimality-theoretic Studies in Spanish Phonology ed. by Fernando Martínez-Gil \& Sonia Colina, 358-377. Amsterdam: John Benjamins.

Yip, Moira. 2004. "Lateral Survival: An OT account". International Journal of English Studies 4:2.25-51.

Zoll, Cheryl. 2001. "Constraints and Representation in Subsegmental Phonology". Segmental Phonology in Optimality Theory ed. by Linda Lombardi, 46-79. Cambridge: Cambridge University Press. 